\title{
Reserve Growth Effects on Estimates of Oil and Natural Gas Resources
}

\section{Introduction}

Many scientists think that the supply of economically recoverable oil and natural gas is geologically limited. However, as recently as early 1999, we experienced a glut of oil on the world market and the lowest inflation-adjusted price of gasoline in history. What is going on? While we cannot provide a comprehensive answer to that question here, we can describe one process that significantly affects the domestic oil and gas industry, a process that also will affect the global industry at some point-reserve growth (also known as field growth).

\section{The Phenomenon of Reserve Growth}

Operators of oil and gas fields in the United States are required to report total annual production and an estimate of proved reserves from each field to the U.S. Department of Energy. These two quantities provide an estimate of the petroleum volume that ultimately will be recovered from a field. Experience shows that over the life of many oil and gas fields, these estimates of ultimate recovery will increase. Figure 1 illustrates reserve growth for the Midway-Sunset oil field in California.

By 1968, 56 years after discovery of the Midway-Sunset field, cumulative production totaled about 1 billion barrels of oil, and proved reserves - the amount of resource known with a high degree of certainty to be available for future production-stood at about 200 million barrels (fig. 1). Ultimate recovery was estimated then at about 1.2 billion barrels. Just 8 years later, in 1976, cumulative production exceeded this estimate of ultimate recovery, proved reserves stood at 400 million barrels, and ultimate recovery was set at 1.65 billion barrels. Twenty years later in 1996, cumulative production had reached 2.3 billion barrels, proved reserves stood at about 500 million barrels, and ultimate recovery was set at 2.8 billion barrels. Over a period of 28 years, long after the discovery of the field, estimates of ultimate recovery more than doubled, from 1.2 billion barrels to 2.8 billion barrels. While this example describes the reserve growth of a very large and somewhat atypical field, the general phenomenon of reserve growth is common to fields of all sizes and types.

\section{Reserve Growth and National Resource Estimates}

Results of the U.S. Geological Survey (USGS) 1995 National Assessment of United States Oil and Gas Resources (Gautier and others, 1996) indicate that the most important future additions to the Nation's petroleum stocks will come from the reserve growth of fields already discovered, not from discoveries of new oil and natural-gas fields. The 1995
National Assessment estimated that about 30 billion barrels of oil would be added to the Nation's petroleum resources from conventional fields that were yet to be discovered (excluding Federal waters), whereas about 60 billion barrels would be added from reserve growth of conventional fields already discovered (fig. 2). For natural gas, about 258 trillion cubic feet would be added from large and small conventional fields that were yet to be discovered, whereas 322 trillion cubic feet would come from the reserve growth of conventional fields already discovered. If continuous-type (unconventional) natural-gas accumulations are added to the reserve growth figures (a notion enlarged upon in a following section), the total reserve growth estimate for gas would increase to 680 trillion cubic feet. Thus, reserve growth is expected to contribute at least twice as much oil and natural gas to the Nation's reserves as new discoveries.

Our understanding of reserve growth is incomplete. We cannot yet analyze the specific effects of individual contributing factors. Estimates of United States reserve growth are based on projections of past reserve-growth patterns rather than on analysis of individual causative elements. Estimating the reserve growth of world petroleum reserves is even less refined because, among other issues, criteria for reporting reserves vary significantly from country to country.

\section{The Components of Reserve Growth}

Factors that contribute to the reserve growth of fields can be grouped into three categories that are not independent of each other:

- Revisions of reserve calculations

- Improvements in recovery percentage

- Delineation of additional in-place oil and gas

\section{Revisions of Reserve Calculations}

Operators in the United States are required by law to report only those reserves that are known with high certainty to be available for production, thus excluding resources that are at all speculative. It follows that one component of reserve growth is the difference between early estimates of recoverable resources, which in the presence of limited data are required to be conservative, and later estimates based on better knowledge of the field. Revisions of reserve calculations are driven by tangible (and expensive) field-development activities such as those outlined below.
Figure 1. Reserve growth of Midway-Sunset field, Calif., discovered in 1912. Data from successive issues (1968-96), International Petroleum Encyclopedia, PennWell Publishing Co., Tulsa, Okla. 


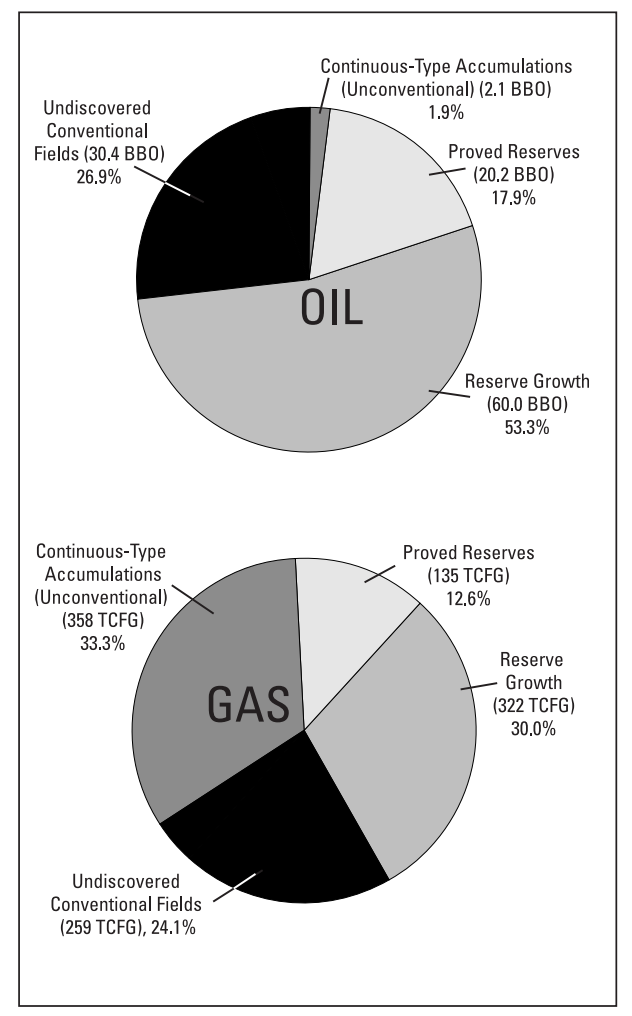

Figure 2. Estimates of technically recoverable oil and gas resources in the United States (excluding Federal waters). In percent and in billions of barrels of oil and trillions of cubic feet of gas. Data from USGS National Oil and Gas Resource Assessment Team (1995) and Gautier and others (1996).

\section{Improvements in Recovery Percentage}

In many U.S. areas, the search for new petroleum reserves has been switching from exploration for new fields to emphasizing extraction of more oil and gas (a higher recovery percentage) from existing fields. Recent successes in applying new technology to lower quality oil and gas accumulations suggest that some known resources that are prohibitively expensive to develop now might become economically available in the future. It is interesting that technology advances do not seem to be strongly dependent upon price levels.

Directional and horizontal drillingAdvances in drilling technology now allow extraordinarily precise control of drilling direction. Multiple wells, directed at targets several miles distant, can be drilled from a single location, and multiple laterals extending in different directions can be drilled from within a single wellbore. Wells can be drilled into a reservoir unit and the bit then directed horizontally, keeping it within a few feet of the top of a thin bed and above the oil-water contact (fig. 3). In complex fields where reservoir geometry limits the volume of petroleum that can be tapped by a vertical well, a horizontal well might produce a greater percentage of the oil or gas in place (fig. 4).
Three-dimensional (3-D) seismic profiling and reprocessing of seismic data.-Where intense exploration and development have created a massive store of information, new methods of processing, analysis, and display of existing seismic data are helping to create reserve growth. Seismic profiles provide a scale diagram of the strata below the surface. Improvements upon two-dimensional seismic profiles made possible by today's fast computers provide 3-D seismic profiles that show a detailed image and precise location of small oil and gas traps, allowing pinpoint targeting of specific features. Time-lapse (4-D) seismic profiling provides, in addition, a time sequence of 3-D seismic images, allowing engineers to view changes in gas, oil, and water contacts as a field is produced. These seismic techniques make production processes more effective and result in improved recovery from identified pools in a field as well as the delineation of additional in-place oil and gas.

Enhanced oil-recovery methods.-In the past, enhanced oil-recovery projects were mostly limited to flooding reservoirs with water. Now, several additional methods have proven to be commercially successful. Carbon dioxide injected in some wells moves oil out other wells. Steam flooding of heavy-oil reservoirs reduces oil viscosity and allows the oil to flow more freely into producing wells. Where these methods are applicable, the recovery percentage can increase significantly.

\section{Delineation of Additional In-Place Oil and Gas}

As a field is developed, drilling tends to extend the field's boundaries. Reserve estimates grow with each increment added to the

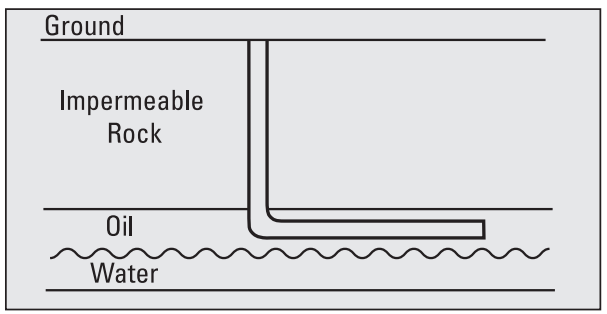

Figure 3. Example of a horizontal well following the top of a thin producing interval or reservoir.

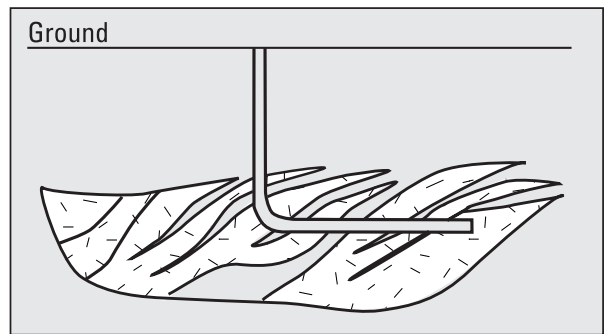

Figure 4. Example of a horizontal well tapping several producing reservoirs in a complex field where producing strata (stippled) and nonproducing strata intertongue. Modified from Finley and others (1990). areal extent of a field. In addition, geological and geophysical analyses coupled with drilling of development wells may find new pods of oil or gas and new petroleum-bearing horizons above or below the initial target.

\section{Continuous-Type Gas Accumulations}

Gas in a continuous-type (unconventional) accumulation is dispersed throughout an extensive reservoir, not localized in discrete fields. A continuous-type accumulation can be regarded as a collection of gas-filled cells, wherein any single well drilled into the accumulation will tap only the limited volume of gas in one cell. The USGS 1995 National Assessment estimated the amount of technically recoverable gas in undrilled cells of continuous-type accumulations to be 358 trillion cubic feet (fig. 2). Because most of the continuous-type accumulations assessed were already discovered, this large volume of gas can best be classified as reserve growth.

\section{The Bottom Line}

The measure of petroleum availability that most affects our economy and our daily lives is the rate at which petroleum can be produced. At some future time, world oil and gas production capacity will decrease as supplies are depleted. The phenomenon of reserve growth is an important component of predictions of future production capacity because it is an integral part of estimates of the world's ultimate supply of petroleum. Recent estimates incorporating reserve growth suggest that the world's ultimate supply of petroleum might be larger than has been generally appreciated.

\section{References Cited}

Finley, R.J., Laubach, S.E., Tyler, Noel, and Holtz, M.H., 1990, Opportunities for horizontal drilling in Texas: Texas University Bureau of Economic Geology Geological Circular 90-2, $32 \mathrm{p}$

Gautier, D.L., Dolton, G.L., Takahashi, K.I., and Varnes, K.L., eds., 1996, 1995 National Assessment of United States Oil and Gas Resources-Results, methodology, and supporting data: U.S. Geological Survey Digital Data Series DDS-30, release, 2, one CDROM.

U.S. Geological Survey, National Oil and Gas Resource Assessment Team, 1995, 1995 National Assessment of United States Oil and Gas Resources: U.S. Geological Survey Circular 1118, 20 p. (Also available online at http:/greenwood.cr.usgs.gov/energy/ execsum.html)

For more information, please contact:

James W. Schmoker

U.S. Geological Survey, MS 939

Denver Federal Center, Box 25046

Denver, CO 80225-0046

Telephone: (303) 236-5794

E-mail: schmoker@usgs.gov 